\title{
Solvent-Free Microwave-Assisted Suzuki-Miyaura Coupling Catalyzed by PEPPSI-iPr
}

Pierrick Nun, Jean Martinez, Frédéric Lamaty*

Institut des Biomolécules Max Mousseron UMR 5247, CNRS, Université Montpellier 1 et Université Montpellier 2,

Place Eugène Bataillon, 34095 Montpellier Cedex 05, France

Fax +33(0)46144866; E-mail: frederic.lamaty@univ-montp2.fr

Abstract: We have developed a new method for Suzuki coupling using an NHC-stabilized palladium catalyst under solvent-free conditions using microwave activation.

Key words: Suzuki reaction, N-heterocyclic carbene catalyst, biaryls, green chemistry, cross-coupling

Palladium-catalyzed cross-coupling reactions are one of the most powerful tools for the formation of carboncarbon bonds and the Suzuki reaction is certainly the most used among them. ${ }^{1,2}$ The coupling of an aryl boronic acid with an aryl halide in the presence of a base provides a simple method to synthesize a large variety of compounds. In recent years, many modifications have been described including the use of diverse catalysts, condi- tions, solvents and bases. The main advances we can quote here are the use of palladium supported on charcoal, ${ }^{3} \mathrm{KF} / \mathrm{Al}_{2} \mathrm{O}_{3}$ or polymers, the use of trihydroxyborate or trifluoroborate instead of boronic acid and diazonium salts in place of aryl halides. ${ }^{4,5}$ Microwaves were also used as an activation technique for Suzuki coupling, ${ }^{6}$ especially with water as solvent ${ }^{7}$ or under solvent-free conditions using a solid support ${ }^{8,9}$ or hypervalent iodonium salt and sodium tetraphenylborate. ${ }^{10}$

One of the main objectives of our research group is to develop clean processes and solvent-free reactions when possible. $^{11}$

Using the reaction of bromobenzene with 4-methoxybenzeneboronic acid, in the presence of potassium carbonate ( 3 equiv), we investigated diverse conditions in order to

Table 1 Optimization of the Reaction Conditions

\begin{tabular}{|c|c|c|c|c|c|c|}
\hline Entry & Time (min) & Temp $\left({ }^{\circ} \mathrm{C}\right)$ & Catalyst (mol\%) & Conversion (\%) & Homocoupling (\%) & Yield $(\%)^{\mathrm{a}}$ \\
\hline 1 & 45 & 60 & PEPPSI (1) & 71 & $-^{\mathrm{b}}$ & $-^{\mathrm{c}}$ \\
\hline 2 & 45 & 90 & PEPPSI (1) & 93 & $-{ }^{\mathrm{b}}$ & $-^{\mathrm{c}}$ \\
\hline 3 & 45 & 110 & PEPPSI (1) & 100 & $-{ }^{\mathrm{b}}$ & 91 \\
\hline 4 & 45 & 130 & PEPPSI (1) & 100 & $-{ }^{\mathrm{b}}$ & 89 \\
\hline 5 & 45 & 150 & PEPPSI (1) & 100 & $-^{\mathrm{b}}$ & 80 \\
\hline 6 & 30 & 110 & PEPPSI (1) & 100 & $-^{\mathrm{b}}$ & 80 \\
\hline 7 & 20 & 110 & PEPPSI (1) & 100 & $-^{\mathrm{b}}$ & 80 \\
\hline 8 & 10 & 110 & PEPPSI (1) & 100 & $-{ }^{\mathrm{b}}$ & 88 \\
\hline 9 & 5 & 110 & PEPPSI (1) & 90 & $-^{\mathrm{b}}$ & $-^{\mathrm{c}}$ \\
\hline 10 & 10 & 110 & PEPPSI (0.5) & 93 & $-{ }^{\mathrm{b}}$ & $-^{\mathrm{c}}$ \\
\hline 11 & 10 & 110 & $\mathrm{Pd} / \mathrm{C} 10 \%$ & 98 & 6.8 & $-^{c}$ \\
\hline 12 & 10 & 110 & $\mathrm{Pd} / \mathrm{C} 10 \%$ & 97 & 9.4 & $-^{\mathrm{c}}$ \\
\hline 13 & 10 & 110 & $\mathrm{Pd}(\mathrm{OAc})_{2}(5)$ & 100 & 9.8 & $-^{c}$ \\
\hline 14 & 10 & 110 & $\mathrm{Pd}(\mathrm{OAc})_{2}(2)$ & 97 & 6.7 & $-^{c}$ \\
\hline
\end{tabular}

a Isolated product.

${ }^{b}$ No homocoupling observed by ${ }^{1} \mathrm{H}$ NMR.

${ }^{\mathrm{c}}$ Not measured with an incomplete conversion. 
optimize time, temperature and amount of catalyst (Scheme 1). We chose to use palladium acetate, palladium supported on charcoal and a new palladium N-heterocyclic carbene catalyst, PEPPSI (Pyridine Enhanced Precatalyst Preparation, Stabilization and Initiation; Figure 1). ${ }^{12-14}$ The results are presented in Table 1.

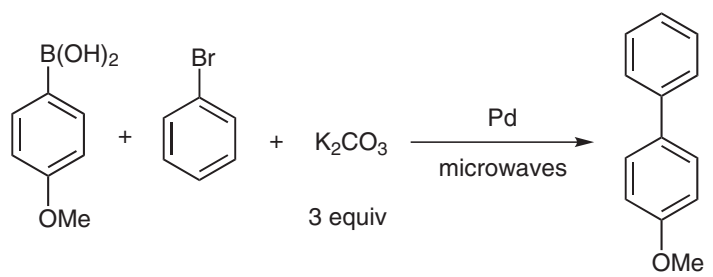

Scheme 1

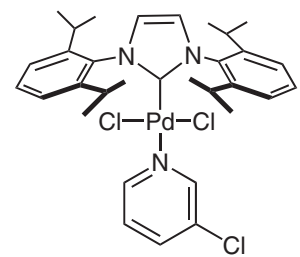

Figure 1 Structure of PEPPSI-iPr

To take complete advantage of solvent-free conditions, a full conversion of reactants into the expected product is required in order to avoid an expensive and solvent-consuming purification step. Furthermore, the homocoupling side reaction needs to be limited. ${ }^{1} \mathrm{H}$ NMR spectroscopy was used to measure the conversion of starting materials and the ratio of homocoupling. As shown in entry 8 , the best conditions were to use $1 \mathrm{~mol} \%$ of PEPPSI-iPr at $110{ }^{\circ} \mathrm{C}$ for 10 minutes. Reducing the quantity of palladium, reaction time or temperature led to a partial conversion of reactants (entries 1, 2,9 and 10). The yields given here were obtained after recovery of the crude mixture with $5 \mathrm{~mL}$ of dichloromethane and filtration in order to eliminate the resulting catalyst and base. Even with full conversion (entries 3-8), however, the isolated yield was slightly lower than $100 \%$ because a small quantity of solvent was used in order to recover the product and some of the product may be still contained in the salts which are not dissolved in water as in a classical extraction. This explains why in certain cases (entries 7 and 8), surprisingly, the yield may be lower after a longer time of reaction because results were obtained from two different experiments.

In order to compare PEPPSI with other catalysts, the same conditions were applied using $\mathrm{Pd} / \mathrm{C} 10 \%$ and $\mathrm{Pd}(\mathrm{OAc})_{2}$ (entries 11-14). We found that, although the results are good compared to those obtained in solution, full conversion was not observed with $5 \mathrm{~mol} \%$ of palladium and, as demonstrated previously using solvent-free conditions, ${ }^{15,16}$ homocoupling was present as an important sidereaction.
In a microwave vial, agitation during the reaction was not strong enough to insure a good homogenization of solid reactants. In order to observe complete conversion, a good homogenization is essential so the mixture of PEPPSI, $\mathrm{K}_{2} \mathrm{CO}_{3}$ and boronic acid should be ground in a mortar to obtain a uniform powder before addition of bromobenzene to the microwave vial. Other methods use the addition of a solvent such as methanol and then its evaporation before the reaction to assure homogenization. ${ }^{8}$ By a "pregrinding' we can avoid this solvent utilization.

In order to confirm the applicability of our method to other boronic acids we prepared a large variety of compounds starting from bromobenzene and various boronic acids (Table 2; entries 1-8).

Table 2 Results Obtained with the Optimized Conditions

Entry Aryl halide

18<smiles>COc1ccc(-c2ccc3ccccc3c2)cc1</smiles> 
Table 2 Results Obtained with the Optimized Conditions (continued)

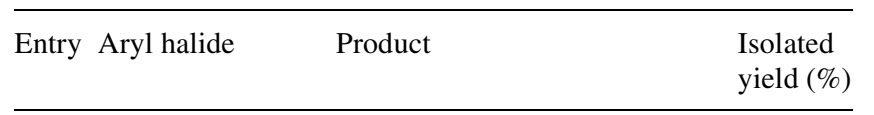

102<smiles>COc1cccc(-c2ccc3ccccc3c2)c1</smiles>

20

112<smiles>Cc1ccc(-c2ccc3ccccc3c2)cc1</smiles>

98

21

$12 \quad 2$<smiles>c1ccc(-c2ccc3ccccc3c2)cc1</smiles>

22

13

2<smiles>c1ccc2cc(-c3cc4ccccc4o3)ccc2c1</smiles>

23<smiles>COc1cc(-c2ccc3ccccc3c2)cc(OC)c1OC</smiles>

24

15<smiles>CC(=O)c1ccc(Br)cc1</smiles>

3

163

17<smiles>CS(=O)(=O)c1ccc(Br)cc1</smiles>

4

$\mathrm{OHC}$

18<smiles>CCc1ccc(Br)cc1</smiles>

5

19<smiles>CC(=O)c1ccc(Cl)cc1</smiles><smiles>CC(=O)c1ccc(-c2ccccc2)cc1</smiles>

98

25

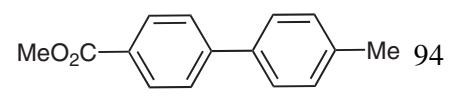

26

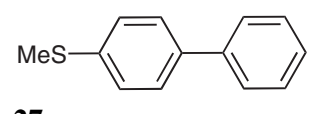

88

27

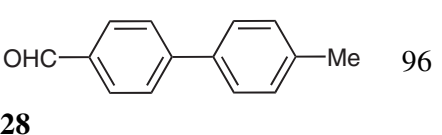

28

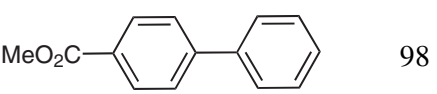

25
Table 2 Results Obtained with the Optimized Conditions (continued)
Entry Aryl halide

7

21<smiles>O=[N+]([O-])c1ccccc1I</smiles>

8

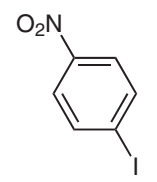

9

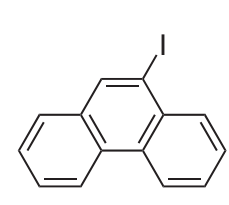

10
Product

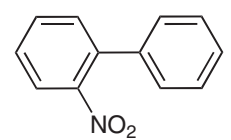

29

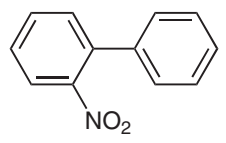

29

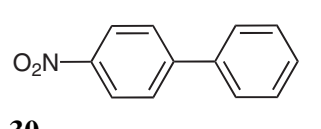

30

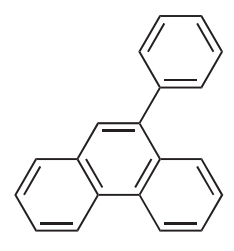

31
Isolated

yield (\%)

96

96

94
It is important to note that bromobenzene can be easily removed under reduced pressure and boronic acid can be eliminated simply by washing the reaction mixture with a $5 \% \mathrm{NaOH}$ aqueous solution. So, in this case, full conversion is not required in order to obtain the coupled product in a pure form - the starting materials could be removed easily without needing more dichloromethane for filtration. This method could not be used with nonvolatile aryl bromides.

In order to demonstrate the efficiency of this method, we also applied it to solid arylbromides such as 2-naphthalene, methyl 4-bromobenzoate, 4-bromothioanisole and 4-bromobenzaldehyde (entries 9-18). With these solid reactants, the yields were particularly high compared to those obtained with bromobenzene. We can explain that by the fact that all the reactants were ground together in a mortar before the reaction and, thanks to this, no aggregates were observed in the microwave vial after the reaction that could retain the product during the filtration step.

We also investigated the reaction starting from chloro and iodo-aryls (entries 19-23). Here again the aryl halides are solid and the yields were very high, even with the less reactive chloro-aryls 6 and 7 . Nevertheless, under our conditions, only compounds with electron-withdrawing groups were reactive enough to achieve complete conversion.

Generally, quantification of the amount of palladium contained in final products arising from the palladiumcatalyzed transformations is not reported, although this information is crucial in the field of bio-active molecules. ${ }^{17}$ 
Using ICP-MS analysis, the amount of palladium remaining in the final product after a simple filtration of the crude mixture was $997 \mathrm{ppm}$. This amount represents 14\% of the initial quantity of palladium used in the reaction, which compares favorably to the $20 \%$ of the initial $\mathrm{Pd} / \mathrm{C}$ recovered in the final product of the Suzuki reaction, ${ }^{18}$ and is all the more significant since the method we have developed uses only $1 \mathrm{~mol} \%$ of initial catalyst. This result can also be compared to the $8000 \mathrm{ppm}$ of palladium and iron remaining after the use of $\mathrm{PdCl}_{2}(\mathrm{dppf}) \cdot \mathrm{CH}_{2} \mathrm{Cl}_{2}$, after column chromatography or washings with tributylphosphine. ${ }^{19}$

In conclusion, we have developed a microwave-assisted method for the synthesis of biaryls. The reaction was performed in the absence of solvent, although a small amount of solvent was used for recovery of the product. This method was based on the use of a new and powerful catalyst and proved to be efficient with a large variety of boronic acids and bromo-, chloro- and iodoaryls. Compared to the existing methods, this methodology is clean, rapid, and efficient.

\section{General Procedures for the Solvent-Free Microwave-Assisted Suzuki-Miyaura Coupling}

Reactions were performed in sealed vessels with a Biotage Initiator $60 \mathrm{EXP}^{\circledR}$ instrument. The temperature was measured with an IR sensor on the outer surface of the reaction vial.

Method A (with liquid halides): The boronic acid $(0.5 \mathrm{mmol})$ was finely ground in a mortar and pestle with $\mathrm{K}_{2} \mathrm{CO}_{3}(207 \mathrm{mg}, 1.5$ mmol, 3 equiv) and PEPPSI-iPr $(0.005 \mathrm{mmol}, 3.4 \mathrm{mg})$. The solid mixture was then charged into a microwave vial before the addition of the liquid halide $\left(0.5 \mathrm{mmol}, 1\right.$ equiv). After $10 \mathrm{~min}$ at $110^{\circ} \mathrm{C}$, $\mathrm{CH}_{2} \mathrm{Cl}_{2}(5 \mathrm{~mL})$ was added and the product was isolated after filtration and evaporation.

Method B (with solid halides): The boronic acid $(0.5 \mathrm{mmol}, 1$ equiv) and the halide ( $0.5 \mathrm{mmol}, 1$ equiv) were finely ground in a mortar and pestle with $\mathrm{K}_{2} \mathrm{CO}_{3}(207 \mathrm{mg}, 1.5 \mathrm{mmol}, 3$ equiv) and PEPPSI-iPr $(0.005 \mathrm{mmol}, 3.4 \mathrm{mg})$. The solid mixture is then charged into a microwave vial then, after $10 \mathrm{~min}$ at $110^{\circ} \mathrm{C}, \mathrm{CH}_{2} \mathrm{Cl}_{2}$ $(5 \mathrm{~mL})$ was added and the product was isolated after filtration and evaporation.

\section{Acknowledgment}

We thank the MENRT, CNRS and the Fondation d'Entreprise EADS for financial support.

\section{References and Notes}

(1) Miyaura, N.; Suzuki, A. Chem. Rev. 1995, 95, 2457.

(2) Sakurai, H.; Hirao, T.; Negishi, Y.; Tsunakawa, H.; Tsukuda, T. Trans. Mater. Res. Soc. Jpn. 2002, 27, 185.

(3) Felpin, F.-X.; Ayad, T.; Mitra, S. Eur. J. Org. Chem. 2006, 2679.

(4) Alonso, F.; Beletskaya, I. P.; Yus, M. Tetrahedron 2008, 64, 3047.

(5) Lipshutz, B. H.; Ghorai, S. Aldrichimica Acta 2008, 41, 59.

(6) Appukkuttan, P.; Van der Eycken, E. Eur. J. Org. Chem. 2008, 1133.

(7) Leadbeater, N. E.; Smith, R. J. Org. Biomol. Chem. 2007, 5, 2770.

(8) Melucci, M.; Barbarella, G.; Sotgiu, G. J. Org. Chem. 2002, 67, 8877.

(9) Basu, B.; Das, P.; Bhuiyan, M. M. H.; Jha, S. Tetrahedron Lett. 2003, 44, 3817.

(10) Yan, J.; Hu, W.; Zhou, W. Synth. Commun. 2006, 36, 2097.

(11) Colacino, E.; Nun, P.; Colacino, F. M.; Martinez, J.; Lamaty, F. Tetrahedron 2008, 64, 5569 .

(12) Kantchev, E. A. B.; O’Brien, C. J.; Organ, M. G. Aldrichimica Acta 2006, 39, 97.

(13) Organ, M. G.; Abdel-Hadi, M.; Avola, S.; Hadei, N.; Nasielski, J.; O'Brien, C. J.; Valente, C. Chem. Eur. J. 2006, $13,150$.

(14) (a) Ray, L.; Shaikh, M. M.; Ghosh, P. Dalton Trans. 2007, 4546. (b) Benakki, H.; Colacino, E.; André, C.; Guenoun, F.; Martinez, J.; Lamaty, F. Tetrahedron 2008, 64, 5949.

(15) Klingensmith, L. M.; Leadbeater, N. E. Tetrahedron Lett. 2003, 44, 765 .

(16) Nielsen, S. F.; Peters, D.; Axelsson, O. Synth. Commun. 2000, 30, 3501.

(17) Garrett, C. E.; Prasad, K. Adv. Synth. Catal. 2004, 346, 889.

(18) Tagata, T.; Nishida, M. J. Org. Chem. 2003, 68, 9412.

(19) Chen, C.-Y.; Dagneau, P.; Grabowski, E. J. J.; Oballa, R.; O'Shea, P.; Prasit, P.; Robichaud, J.; Tillyer, R.; Wang, X. J. Org. Chem. 2003, 68, 2633. 